\title{
Janice Rodway's Ideal Romance in Hero (Christian Grey) and Heroine (Anastasia Steel): An Analysis of Fifty Shades of Grey by E.L James
}

\author{
Kinanti Resmi Hayati \\ UPN "Veteran" Jawa Timur \\ E-mail: Kinantihayati.ti@upnjatim.ac.id \\ Fikry Zahria Emeraldien \\ UPN "Veteran" Jawa Timur
}

\section{Article History}

Received: 1 February 2019

Accepted: 9 April 2019

Published: 29 April 2019

\begin{abstract}
Christian Grey and Anastasia Steel are the main character in trilogy of Fifty Shade by E.L James. This novel is one of the best popular literatures in $21^{\text {st }}$ century. This study focuses on analyzing both main characters by using ideal romance by Janice roadway which is portrayed in first trilogy of Fifty Shades. There are some terms in ideal romance; two of them are the ideal of hero and the ideal of heroin. This study focuses to look deeper into character of Christian grey as the hero and Anastasia steel as the heroin. This study also discusses about their sexual behavior and relation as part of romance popular literature today. This study is using textual analysis approach and genre analysis theory to analyze the problem. Whether Christian Grey and Anastasia Steel has all the ideal categories of hero and heroine which is based on Roadway's ideal romance. However, there are some pro and cons in the result of discussing about the main characters depicted in Fifty Shades of Grey.

Keywords: Ideal romance, genre, hero, heroin, popular literature.
\end{abstract}

\section{Introduction}

Sexual issue has become trending topic nowadays in popular literature world. It started when the novel of Fifty Shades of Grey by E.L James published in 2011. This novel has become a great phenomenon in $21^{\text {st }}$ century in popular literature world because of its content. These novels are produced in trilogy sessions; those are Fifty Shades of Grey, Fifty Shades of Darker, and Fifty Shades of Freed. This novel is one of romance popular literatures in America. Trilogy of Fifty Shades becomes very popular in America based on the number of its selling. Based on goodreads.com as one of the biggest website for book review, Trilogy of Fifty Shades has 4.15 from 5 stars for its rating. The number of Fifty Shades book selling is very high in America. This novel sold 1 million copies in its first week of publication and until now, there are 125 million copies book has been sold in worldwide. This novel is not only popular in America but also in over the world. Trilogy of Fifty Shade has been translated into 52 languages as a new book in popular literature. That's why Fifty Shades is categorized as popular literature based on its selling number.

Trilogy of Fifty shades has been successfully changed the people's mind about the term of sexuality. In the past, sexuality is taboo for discussing in the book or novel but today it is not taboo anymore. This paper will discuss about the issue of sexual exposure in trilogy of Fifty Shades as the main topic of the novel. It is quite taboo if we dont discuss about sexuality in Trilogy of Fifty shades. A sociology professor at the Hebrew University, Eva Illouz, said that Trilogy of Fifty Shades are some of the worst 
Doi: http://dx.doi.org/10.30651/tell.v7i1.2653 writing she has ever seen and a plot that made her toenails curl - the erotic novel - is less pornographic than it is a self - help book. ${ }^{1}$ From the point of view of professor Illouz, Trilogy of Fifty Shades is not merely an erotic romance literature but more as functional book. This thought makes trilogy of Fifty Shades becomes more popular which is not only as novel but also as book that can makes the reader to enjoy reading the book and get the pleasure.

Trilogy of Fifty Shades tells about the love story between Christian Grey and Anastasia Steel. The plot of the story is not different with the other of romance of popular literature. The fairy tales theme was main theme that always used in popular literature. Anastasia steel described as innocent girl from middle class society then, meet with Christian grey as handsome and rich guy. One thing that makes this novel different is the way how the author expresses her words into explicit way even when she tells about the sexuality. Based on Catherine Millet, the French author said that a pornographic book is functional written to help us to get excited, if we want to speak about sex in a novel or any ambitious writing in the $21^{\text {st }}$ century, we must be explicit and cannot be metaphorical any longer. ${ }^{2}$

This paper will specifically discuss about the analysis of ideal romance by Janice roadway depicted in Fifty Shades of Grey. This paper will focused on the character of Christian Grey and Anastasia Steel portrayed in first trilogy of Fifty Shades. Based on Janice Roadway, there are some terms in ideal romance; two of them are the ideal of hero and the ideal of heroin. The writer will focus to look deeper into character of Christian grey as the hero and Anastasia steel as the heroin. It is not only discussing about their character but also their sexual behavior and relation as part of romance popular literature today. The main research problem of this paper is how the ideal of hero and heroine portrayed in Fifty Shades of Grey is. As an additional question for the conclusion the writer want to reveal about is there any pro and contra about sexual exposure in Fifty Shades of Grey based on narrative romance by Janice Roadway? This paper is using textual analysis approach to analyze the problem. The theory that will be used is genre analysis. The writer will focus on the text and formula of the novel to find out the result of the problem. This paper will be semantic analysis because this paper will focus only on Fifty Shades of Grey and will look deeper into the novel.

\section{THEORITICAL APPROACH}

\section{GENRE ANALYSIS}

Based on Cawelty's book of Adventure, mystery, and romance: formula stories as art and popular culture, she stated that in general, a literary formula is a structure of narrative or dramatic conventions employed in a great number of individual works. There are two common usages of term formula closely related to the conception. The first usage simply denotes a conventional way of treating some specific thing or person. The important thing to note about this usage is that it refers to patterns of convention which are usually quite specific to a particular culture and period and do not mean the same outside this specific context. The second common literary usage of the term formula refers to larger plot types. ${ }^{3}$ 
Doi: http://dx.doi.org/10.30651/tell.v7i1.2653 In finding hero and heroine in the novel, the writer will use the concept of the ideal of hero and the ideal of heroine by Roadway.

This paper is used genre analysis to analyze the paper. As known that formula is part of genre analysis but in this paper, it will focus on the character of the hero and heroine itself. Based on Roadway that a genre is never defined solely by its constitutive set of functions, but by interaction between characters and by their development as individuals. As a result, she has assumed further that the romantic genre is additionally defined for the women by a set of characters whose personalities and behaviors can be "coded" or summarized through the course of the reading process in specific ways. 4

Based on the statement above, it explains that romantic genre usually deals with the function of character in the story. Hero and heroine have an important part in romantic genre especially in popular literature. The analysis of this paper will deal between the roadway's theory of ideal romance in popular literature especially in ideal of hero and ideal of heroine and a novel of Fifty Shades of Grey by E.L James. Based on roadway's book, she stated that it has given this emphasis on her tomboyish defiance and her verbal facility; it is not hard to understand why The Smithton readers describe their favorite heroines as "intelligent," "spunky," and "independent."5

\section{FINDING AND DISCUSSION FINDING}

The ideal of heroine should have three main characters in her characteristic. Those are intelligent, spunky, and independent. Usually, female character in the story always describes as submissive one or under the patriarchal gender role. They usually describes as beautiful woman with kind heart, feminine, dependent, and so on. But nowadays, in popular literature, most of women readers want to get an enjoyable reading for their reading. They want to read some stories that make them happy by giving a specific characteristic for the heroine. The characters of intelligent, spunky and independent are most of favorite heroine character by women readers. As known that most of romance popular literature readers are woman. Here, the writer wants to find out the ideal of heroine in Fifty Shades of Grey by E.L James which is characterized by Anastasia Steel as the heroine in the novel. Fifty Shades of Grey is one of the most popular romance literatures in $21^{\text {st }}$ century even there is a touch of sexual exposure in the novel.

"You have a very impressive GPA. What extra-curricular activities did you indulge in at WSU?" Indulge? I blink at him. What an odd choice of word. I launch into details of my librarianship at the campus central library, and my one experience of interviewing an obscenely rich despot for the student magazine. I gloss over the part that I didn't actually write the article. I mention the two literary societies that I belonged to and conclude with working at Clayton's and all the useless knowledge I now possess about hardware and DIY. (James, 2011: 264-265)

The quote above shows us about the intelligent character of the heroine, Anastasia Steel. She is the student in WSU Vancouver. She took literature as her major studies. When she was graduated, she also got an impressive score for her GPA. It already shows that she is intelligent. She also showed her intelligent by writing an article and being part of student magazine in campus. She ever had an interview with rich man while she worked in magazine campus. She also worked in library as librarian 
Doi: $h$ ttp://dx.doi.org/10.30651/tell.v7i1.2653

while she was student in WSU Vancouver. It explains that the heroine (Anastasia Steel) is intelligent as one of the top three character as the ideal of heroine in romance popular literature.

Okay. I can do this. I bend over the smooth soft leather. He's left my bathrobe on. In a quiet part of my brain, I'm vaguely surprised that he hasn't made me take it off. Holy fuck this is going to hurt... I know. My subconscious has passed out, and my inner goddess is endeavoring to look brave. (James, 2011: 350)

The heroine (Anastasia Steel) in the novel is not only intelligent but also spunky or in other word is brave. In the quotes above, she showed her brave character while she was with Mr. Grey. She always felt submissive when she was around Mr. Grey but in this part, she could show her brave look. In other part of the story, she also described that she was spunky young girl. While not many women can argue with Mr. Grey, she can deliver her opinion under the dominance of Mr. Grey. The heroine thought that she was smart enough so she could freely deliver her opinion to anyone about anything include to Mr. Grey. Even in the last story she was subjected under the dominance of Mr. Grey but the heroine still can reconcile it with her will.

I've worked at Clayton's since I started at WSU. It's the largest independent hardware store in the Portland area, and over the four years I've worked here, I've come to know a little bit about most everything we sell - although ironically, I'm crap at any DIY. I leave all that to my dad. I'm much more of a curl-up-with-a-book-in-a-comfy-chair-by-the-fire kind of girl. I'm glad I can make my shift as it gives me something to focus on that isn't Christian Grey. We're busy - it's the start of the summer season, and folks are redecorating their homes. Mrs. Clayton is pleased to see me. (James. 2011: 18)

Anastasia Steel is not only described as intelligent and spunky, but also independent. Based on the quote above, it is very clear that she was independent enough as young girl. She lost her father while she was very young and she lived with her mother and step father. Even her mother got divorce with her step father and decided to remarry again with another men, Anastasia Steel decided to live with her step father. She doesn't want to make her step father in difficult condition, so she decided to work part time to pay her school fee without giving any burden to her step father. She started to work in Clayton since her first year in WSUV. It explains that she could pay her school fee by her own money without depend on other people. She could live well in the city by her own way.

However, the true heroine is not enough only by those top three character of ideal of heroine. In romance popular literature, sexual is one of the most important part in the story. How the heroine behaves about the sexuality. In romance popular literature, heroine usually describes as virgin and has no experience in sex. Based on Roadway's book, it stated that the Smithton readers all approve of the romantic heroine's inexperience and code it as "true innocence" They believe that her lack of knowledge is entirely plausible not to mention desirable as well. They approve of her virginity, however, less on the basis of its status as an abstract moral principle than in accordance with their belief that a woman must protect herself from the many men who desire only her body and care little for her needs. According to these readers, female sexual response is something to be exchanged for love and used only in its service. ${ }^{6}$

"You know I like you Ana, please." He has one hand at the small of my back

holding me against him, the other at my chin tipped back my head. Holy f***. 
Doi: http://dx.doi.org/10.30651/tell.v7i1.2653

he's going to kiss me."No José, stop no." I push him, but he's a hard wall of muscle, and I cannot shift him. His hand has slipped into my hair, and he's holding my head in place. (James, 2011: 45)

From the quote above, Anastasia Steel as the heroine show her true innocence by rejecting a kiss from her best friend Jose. Even though Jose has clarified his love to Ana that he loves her but Ana rejected it. Jose is her best friend but she cannot her heart to her friend. As Heroine, she will give her virginity to her love only include her kiss. So that's why, when Jose tried to kiss her brutally, she tried very hard to rejected it. According to the Smithton readers that as ideal of heroine, she should keep her virginity no matter how from the man who only ask for her body only. But she will give her virginity to the one she love. It happened to Anastasia Steel because she tried so hard to reject Jose's Kiss but in the last part she gave her virginity to her love, Mr. Christian Grey.

After discussing about the ideal of heroine, in this part the writer will discuss about the ideal of hero. If the ideal of heroine has top three $f$ characters, the ideal of hero will also has top three of character. The concept of character for hero in the story always relates to the good things. Hero always describe as handsome guy, rich, intelligent, gentlemen, strong and so on. But based on Roadway's book, she said that the combination of this self-protective aggressiveness and the fleeting revelation of his underlying capacity for gentleness is responsible, then, for the Smithton readers' tendency to describe the ideal heroin paired terms. When asked in the interviews to provide an account of the perfect romantic hero, Dot and her customers replied with such phrases as "strong but gentle," "masculine but caring," "protective of her and tender," "a he-man but a lover-boy, too. "7

There are top four characters of the ideal of hero based on Smithton readers. Those are strong but gentle, masculine but caring, protective and tender, and a man but lover boy too. These four characters have opposition concept, masculine and feminine. The hero should be strong but in the same time he should be gentle, he must be masculine but he requires being caring. In other occasion, the hero has to be protective and tender in the same time. The main duty of hero is not only for being the real man but also a lover boy too. These four concepts of character will make hero seem perfect for the readers especially woman reader. In romance popular literature, the hero should describe as perfect as possible. Even though the Hero has a lack in the story but it doesn't matter because he has many good thing to cover his lack. The writer will find out the top four characters of the ideal of hero in Christian Grey's character in Fifty Shades of Grey.

Gripping his upper arms, I feel his biceps, he's surprisingly strong... muscular. Tentatively, I move my hands up to his face and into his hair. Holy Moses. It's so soft, unruly. I tug gently, and he groans. He eases me toward the bed, until I feel it behind my knees. I think he's going to push me down on to it, but he doesn't. (James, 2011: 82)

Based on this quote, Mr. Grey described as strong man. He had muscle in his arm and biceps also. His appearance was described as very perfect man's body. Mr. Grey is very sexy. He is handsome, rich, smart, good-look body, and dominance. Mr. Grey was strong physically and mentally. He had good-look body. He won when he fights with Jose. He liked to exercise in order to keep her health and body shape. He was also strong mentally. He could survive from all the burdens that he ever had while he was pretty young. He lost his biological mother when he was four years old. He 
Doi: http://dx.doi.org/10.30651/tell.v7i1.2653

could survive from her tragic moment when he was fifteen years old. Even though he was strong but he was also gentle. He knew when he had to use her power. He tried to be gentle when he was with Anastasia Steel. He didn't want to hurt Anastasia Steel and being gentle to her.

His expression softens as I carefully make my way through my breakfast. I note that he cleans his plate. He waits for me to finish, and then he clears my plate. "You cooked, I'll clear." “That's very democratic." (James, 2011: 94)

Mr. Grey also described as masculine man but also caring person. From the quote above, he was very masculine while she took care of the plate after eating together. His masculinity was showed by his caring to Anastasia Steel. He knew how to make women feel respected by man. He cleaned up the plate after their breakfast. He realized as good man he had to clean up the plate after knowing that the woman had already cooked for their breakfast. His behavior and attitude to Anastasia steel when they had have breakfast together shows how masculine and caring he is. Her democratic point of view is one way to show his masculinity. He was handsome, rich and dominance but he was not shy to clean up the plate. Masculine and caring are being one packet for his character as ideal of hero in the story.

And for all that, I have spent the night in his hotel suite, and I feel safe. Protected. He cares enough to come and rescue me from some mistakenly perceived danger. He's not a dark knight at all, but a white knight in shining, dazzling armor - a classic romantic hero - Sir Gawain or Lancelot. (James, 2011: 52)

The quote above declares that Anastasia Steel thinks that Mr. grey is perfect one. He is protective and tender. His character makes Anastasia steel comfort with him. The most important thing for women when she loves someone is when she felt being protected, care, and rescued her from any danger. His tenderness makes Anastasia Steel as perfect woman. Mr. Grey is not only protective and tender because he is not only as perfect man but also lovely boy too. Anastasia thinks that Mr. Grey is White knight in shining, dazzling armor, and Lancelot. Those are the expression to show how perfect man and lovely boy he is.

These top four characters of the ideal of hero are not enough because the Smithton readers also have others types for the ideal of hero. Based on Roadway's book, she stated that the Smithton readers volunteered the information that an ideal hero must be "a man among men," as one of Dot's customers explained. When asked to gloss her encomium, this woman added that he must be a "leader" able "to command respect from everyone around him." In fact, her observations accurately describe the social status shared by the heroes of these twenty romances. Not only are they wealthy, indeed, often aristocratic, but they are also active and successful participants in some major public endeavor. ${ }^{8}$

Those top four characters of the ideal of hero; strong but gentle, masculine but caring, protective and tender, and man but lover boy too is not the only main character for hero's character in $20^{\text {th }}$ century of romance gender. The hero should be able to be a leader among men. Beside hero should be wealthy, handsome and aristocratic, he should be success and active in public endeavor too. A concept of wealthy and aristocrat is too yesterday for today's romance popular literature. So that's why, the hero is demanded to be success and active in public. The concept of kingdom and noble family does not too exist anymore in romance genre especially in popular literature. 
Doi: http://dx.doi.org/10.30651/tell.v7i1.2653

Most of reader wants to read some stories that still relates to the real world which the hard worker and active in public is the success man.

"I don't subscribe to luck or chance, Miss Steele. The harder I work the more luck I seem to have. It really is all about having the right people on your team and directing their energies accordingly. I think it was Harvey Firestone who said "the growth and development of people is the highest calling of leadership." (James, 2011: 10 -11)

From the quote above, it stated that Mr. Grey was hard worker man. He didn't believe of luck and chance but he believes of hard work. He was only common man when he was young but he realizes that by having hard work he will be success. He started his business since he was young. He found his right man for his team and directs their energies to his purpose. Even Mr. Grey had wealth family background, but he didn't want to rely on them. So that's why, he started to make her own business and being success by his own way. It makes the readers fall in love with the hero character of Mr. Christian Grey especially woman reader because he can achieve his successful in young age by his work hard. Work hard is one of the American character.

\section{DISCUSSION}

Sexuality or sexual behavior of the hero cannot be separated from the ideal of hero in romance genre. The sexual behavior of Mr. Grey is very interesting to discuss. Many readers interesting to buy this novel because of the sexual exposure of Mr. Grey and Anastasia Steel portrayed in the story. However, based on roadway's book, she stated that the Smithton readers are aware of the fact that even an ideal romantic hero has had sexual experiences before his encounters with the heroine. In fact, in these romances, the heroine's innocence is often contrasted explicitly with the hero's previous promiscuity, behavior that is made tolerable to both the heroine and the reader because it is always attributed to his lack of love for his sexual partners. 9

"You're a virgin?" he breathes. I nod, flushing again. He closes his eyes and looks to be counting to ten. When he opens them again, he's angry, glaring at me."Why the $\mathrm{f}^{* * *}$ did not you tell me?" He growls (78).

Based on the quote above, it explained that Mr. Grey is well experience enough because it is for his first time having sex with a virgin. He is very shock while he knows that Anastasia Steel is still virgin. Mr. Grey usually makes love with woman who expert in it. It clearly shows how the sexual behavior of Mr. Grey is. He is very shock because he afraid that he will hurt Anastasia while they are having sex because what Mr. Grey wants for sex is not an vanilla sex or ordinary sex but an extraordinary sex. Mr. Grey is not perfect in his appearance or his career but also his sexuality. The table bellow will show us how the binary opposition in character is in romantic narrative.

Table 1

Binary Oppositions in Character Portrayal at Beginning of the Romantic Narrative ${ }^{10}$

\begin{tabular}{|l|l|l|l|l|l|l|}
\hline $\begin{array}{l}\text { Oppositional } \\
\text { Pair }\end{array}$ & Heroine & $\begin{array}{l}\text { Female } \\
\text { Foil }\end{array}$ & Hero & Male Foil & Oppositional & $\begin{array}{l}\text { Pair } \\
\text { Villain }\end{array}$ \\
\hline Virginal & + & - & - & Uncoded & Virginal & - \\
Experienced & - & + & + & Uncoded & Promiscuous & + \\
\hline
\end{tabular}




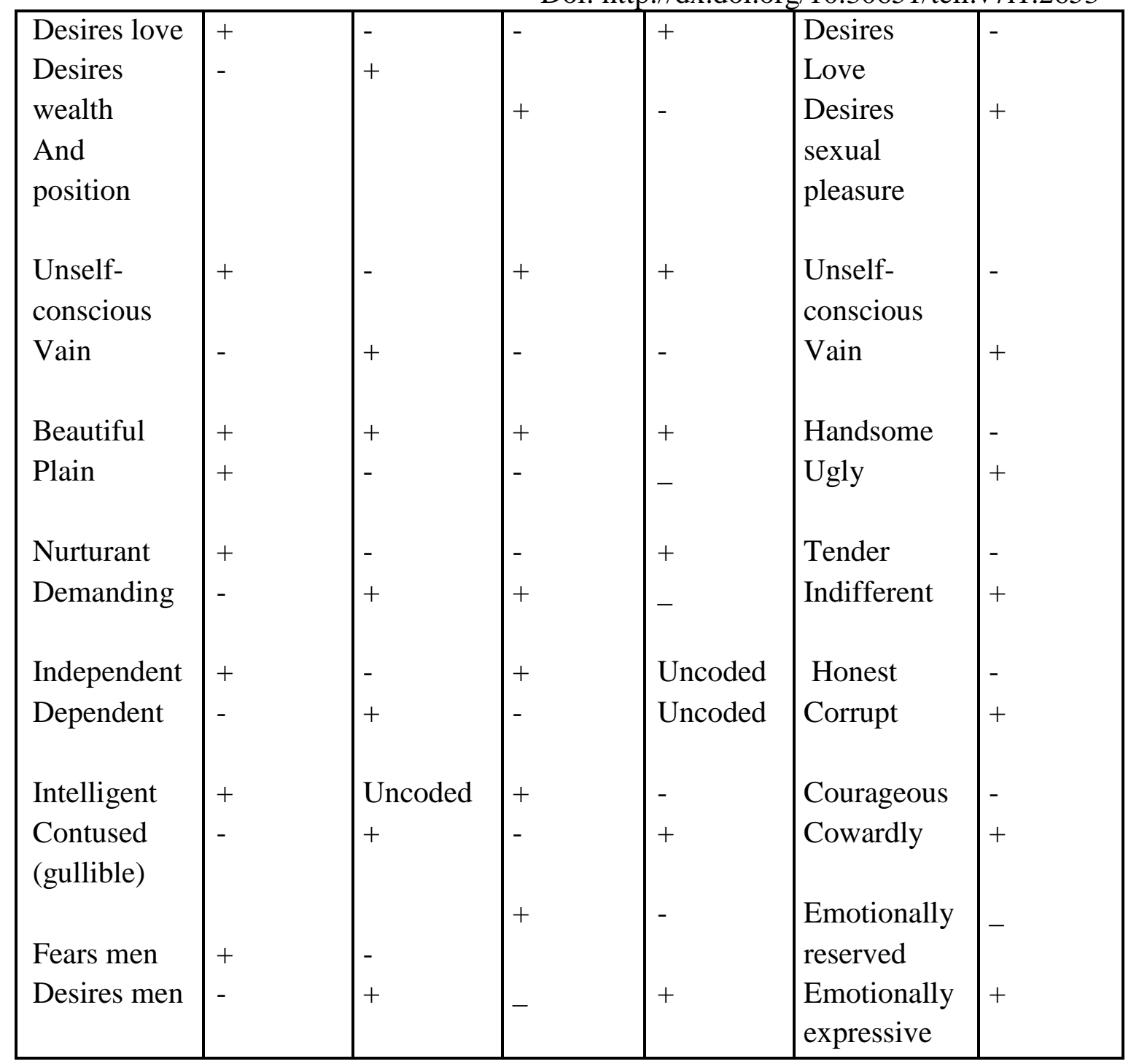

The table above describes how to differentiate between the heroine and the female foil. Based on Roadway's book that heroines should be virgin and inexperience in sex, they only attract to love and not to the wealth or anything else from men. They should be unselfconscious and not to be vain. They are also beautiful, plain, nurturant but not demanding. They are independent but not dependent and intelligent but not contused. They fears with men but not desire to him. The categorize for female foil character is the opposite of heroine's character. Anastasia Steel is virgin and inexperience in sexual act. She only attracts to Mr. Grey's love rather than his wealth. She is very unselfconscious and not vain. She is beautiful, plain in her appearance and way of life, nurturant and not demanding with her life. She is an independent young woman and also intelligent. She is not dependent and she cannot be contused But, Anastasia Steel does fear with Mr. Grey and she desires to him very much. This term makes Heroine' character in this novel is different with other heroine's character in romance popular literature

Based on the table above, Heroes do not need to be virginal but they should be promiscuous. They are interested with sexual pleasure rather than love. They are usually vain and not unselfconscious. They are handsome, honest, tender, and courageous but not ugly, corrupt, indifferent, and cowardly. They are more expressive emotionally rather than emotionally reserved. The character of male foil is the opposite 
Hayati, Emeraldien, Tell : Teaching of English Language and Literature Vol. 7, No. 1, 1-10, April 2019

Doi: http://dx.doi.org/10.30651/tell.v7i1.2653

of hero's character. In the story of Fifty Shades of Grey, Mr. Grey is not virgin but he is promiscuous. He is more interesting to sexual pleasure with Ana rather than her love. $\mathrm{He}$ is very vain with his luxurious condition and not unselfconscious at all. $\mathrm{He}$ is handsome, honest, tender and courageous but he is not ugly, corrupt, indifferent, and cowardly. Something different from the term is Mr. Grey is not emotionally expression but rather emotionally reserved. He is not able to express his love to Anastasia but he is more emotionally reserved. This thing is make him different from other heroes in romantic popular literature. It makes him look sexier with his stolid character especially in expressing her emotion to other people.

\section{CONCLUSION}

In conclusion, Anastasia Steel has all the categories of the ideal of heroine based on Roadway's ideal romance. She is intelligent, independent, and spunky. She is also still virgin and inexperience in sexual activity. She keeps her virginity to any men who only desire with her body and gives her virginity to her love. Mr. Christian Grey is also has all the categories of the ideal of hero based on Roadway's ideal romance. He is strong but gentle, protective and tender, masculine but caring, and he is not only perfect man but also lover boy too. He is also success in her business career and active in public. He can be a leader among men with his ability. He is well experience in sexual activity. But, there is still pro and contra this paper's result with roadway's theory, based on roadway's theory that woman may not desire to man and should fear with man. It is not happened to Anastasia Steel because she desires to Mr. Grey so much and doesn't fear with him at all. As Hero, Mr. Grey should be emotionally expression and not emotionally reserved. Meanwhile, Mr. Grey cannot express her emotional well to other people especially about love. This difference makes Fifty Shades of Grey is more interesting to read rather than any other romance popular literature. As known that Fifty Shades of Grey has become the best seller ever of romance popular literature in $21^{\text {st }}$ century. In Roadway's book stated that sexuality is not the main term in romance genre. But nowadays, sexuality is being one of the most important things in romance popular literature. By exposure the sexual activity in fifty Shades of Grey, E.L James is very success in selling her first novel.

\section{References}

Bressler, Charles E. (2002) Literary Criticism - An introduction to Theory and Practice. New Jersey: Prentice Hall.

Cawelty, J.G. (1976). Adventure, Mystery, and Romance: Formula Stories as Art and Popular Culture. Chicago: University of Chicago Press.

Flood, Alison. "Fifty Shades of Grey is really a self-help book, says academic". 20 August 2014. Web. 3 December 2015. http://www.theguardian.com/books/2012/jul/06/fifty-shades-of-grey-is-really-aself-help-book-says-academic.

Hall, Stuart. (1997). Representation: Cultural Representations and Signifying Practices. London: Sage Publication.

http://www.goodreads.com/book/show/13584236-fifty-shades-trilogy

James, E. L. (2011). Fifty Shades of Grey. New York: The Writer's Coffee Shop.

Radway, Janice A. (1991). Reading the Romance: Woman, Patriarchy, and Popular Literature. Chapel Hill and London: The University of North California Press. 
Hayati, Emeraldien, Tell : Teaching of English Language and

Literature Vol. 7, No. 1, 1-10, April 2019

Doi: http://dx.doi.org/10.30651/tell.v7i1.2653

Sandika, Edria and Marliza Yeni. Construction of Gender and Social Class as Found in The Novel Fifty Shades of Grey by E.L James. Padang, Indonesia: Andalas University

Selden, Raman, Peter Widdowson, Peter Brooker. (2005). A Reader's Guideto Contemporary - Literature Theory. Edinburgh: Pearson Longman.

Storey, John. Cultural Theory and Popular Culture: An Introduction (5eds). England: Pearson Longman.

Tyson, Lois. (2006). Critical Theory Today. New York: Routledge.

William, Zoe. "Why women love Fifty Shades of Grey". 21 May 2014. Web. 3 December 2015. http://www.theguardian.com/books/2012/jul/06/why-womenlove-fifty-shades-grey.

Vinberg, Kristina. (2012). Fairy Tale Narratives \& Notions of Gender in Stephenie Meyer's Twilight Saga and E.L James' Fifty Shades Trilogy. Sweden: Lund University. 